\title{
ЦІННІСНІ ОРІЄНТАЦІЇ СЛУХАЧІВ ЯК НЕОБХІДНА ПЕРЕДУМОВА ФОРМУВАННЯ КОМПЕТЕНТНОГО ВІЙСЬКОВО-МЕДИЧНОГО ФАХІВЦЯ
}

\author{
І.С. Трінька, В.В. Кальниш, Н.І. Мудрик, О.В. Числіцька
}

Українська військово-медична академія, м. Київ, Україна

Вступ. Формування компетентного військово-медичного фахівия $\epsilon$ процесом складним, який визначається не тільки сумою отриманих професійних знань, умінь та навичок, сформованих компетентностей, але й системою ціннісних орієнтацій, ціннісної самосвідомості молодого фахівця. Процес ціннісного виховання військового, військового медика зокрема, потрапляє до стратегічних інтересів нашої держави.

Метою дослідження було виявити ціннісні орієнтації і життєві пріоритети у слухачів першого курсу УВМА для подальшого стимулювання їх розвитку або проведення корекції впродовж навчання в УВМА.

Матеріали і методи. У дослідженні був використаний опитувальник з 18-ти тверджень щодо особистих ціннісних орієнтацій. Опитано 119 слухачів першого курсу УВМА.

Статистичний аналіз даних проведено з використанням методів варіаційної статистики, кореляційного (коефіцієнт кореляції Спірмена), кластерного та покрокового дискримінантного аналізу 3 допомогою пакету програм STATISTICA 13.3. Ліцензія AXA905I924220FAACD-N.

Результати. Аналіз виявлених ціннісних орієнтацій слухачів показує, що їм притаманні цілком природні особистісні цінності пересічної молодої людини (найважливішими цінностями у житті слухачів $\epsilon$ фізичне і психічне здоров'я, щасливе сімейне життя, любов). Але вони не виявляють зацікавленості в розвагах, творчості, красі природи та мистецтва. Результати дослідження дають підстави зробити висновок, що молоді люди, які тільки починають навчатися в УВМА, почувають себе не надто впевненими в новому для них військовому середовищі. Експериментально отримані результати рейтингу ціннісних орієнтацій з допомогою кластерного аналізу методом k-середніх дали змогу виділити дві підгрупи з різним профілем пріоритетів з наближеним співвідношенням кількості осіб у першій та другій підгрупах як 1:2. За своїми ціннісними орієнтирами представників першої підгрупи можна охарактеризувати як активних, самостійних, незалежних у діях і судженнях, орієнтованих на особисте удосконалення, професійне зростання, розширення власного світогляду з дещо егоїстичним проявом своїх пріоритетів. Для підгрупи 1 пріоритетними цінностями на сучасному етапі життя є здоров'я (фізичне і психічне), продуктивне життя (максимально повне використання своїх можливостей, сил, здібностей), розвиток (робота над собою, постійне фізичне і духовне удосконалення, свобода (самостійність, незалежність в судженнях $i$ вчинках), впевненість у собі (внутрішня гармонія, свобода від внутрішніх протиріч і сумнівів). Навчання в академії вони розглядають як майданчик для реалізації своїх життєвих планів. Вибрані представниками 2ї підгрупи твердження дозволяють зробити висновки, що їх життєві цінності орієнтовані на здорове, сімейне, матеріально забезпечене, урівноважене життя. Військова служба може розглядатися як основа $і$ необхідне джерело для забезпечення такого життя. Враховуючи, що активна життєва позиція, можливість творчої діяльності для них є неважливими, а цікава робота, можливість особистого розвитку, продуктивне життя з використанням свої здібностей і можливостей займають проміжне значення, можна припустити, що вони готові виконувати шаблонну роботу, підпорядковуватися наказам. Це люди «команди», для яких значимими є колектив, його принципи, громадська думка. Система ціннісних орієнтацій в цій підгрупі є стабільнішою, ніж в підгрупі 1, свідчить про потенційно кращу спроможність адаптації до змін зовнішнього середовища.

Висновки. Система ціннісних орієнтацій слухачів перебуває на стадії ї̈ завершення. Особливу увагу при організації освітнього процесу слід приділяти формуванню у слухачів активної життєвої позиції, орієнтованої на відповідальне ставлення до власного професійного зростання та суспільного життя, формуванню національно-патріотичних почуттів.

Ключові слова: життєві цінності, ціннісні орієнтації, внутрішня гармонія, особисте удосконалення, професійне зростання, активна життєва позиція.

Вступ. У Законі України «Про освіту» визначено, що «метою освіти $є$ всебічний розвиток людини як особистості та найвищої цінності суспільства, її талантів, інтелектуальних, творчих і фізичних здібностей, формування цінностей і необхідних для успішної самореалізації компетентностей, виховання відповідальних громадян, які здатні до свідомого суспільного вибору та спрямування своєї діяльності на користь іншим людям і суспільству, збагачення на цій основі інтелектуального, економічного, творчого, культурного потенціалу Українського народу, підвищення 
освітнього рівня громадян задля забезпечення сталого розвитку України та ії̈ європейського вибору» [1].

Беручи до уваги, що поняття компетентність розглядається не лише як динамічна комбінація знань, умінь, навичок, але і способів мислення, поглядів, цінностей особистості випускника вищої школи, завданням освітнього процесу вищого навчального закладу $є$ посилення виховного впливу, створення освітніх технологій, здатних забезпечити ефективність опанування молоддю цінностей подальшого життя і їх успішну адаптацію в професійній діяльності.

Вища школа виступає тією інституцією, яка повинна відповідати духовним запитам молоді, забезпечувати її професійне становлення та задовольняти соціальне замовлення не тільки в підготовці висококваліфікованих фахівців, але і $\epsilon$ провідним центром формування інтелектуальної, наукової, творчої еліти 3 духовними ціннісними орієнтаціями, гуманістичним світоглядом та національною самосвідомістю [2].

Формування ціннісної свідомості, ціннісних орієнтацій $€$ основною метою $\mathrm{i}$ завданням виховання. Зміна цінностей приводить до зміни цілей виховання, тому виховання визначається як цілеспрямована діяльність 3 метою формування або зміни світоглядної, почуттєвої і культурноповедінкової ціннісної системи індивіда $[3,4]$.

Наукові дослідження ціннісної свідомості сучасної студентської молоді (I. Бех, Д. Бітінас, Б. Бім-Бад, Є. Бондаревська, Н. Голованова, Л.Г. Сокурянська та інші) констатують знецінення у їх середовищі патріотичної, героїчної і альтруїстичної поведінки, девальвацію у студентській свідомості громадянських якостей, почуття обов'язку і відповідальності, причетності до соціально-політичних процесів, що відбуваються в суспільстві. Ці науковці стверджують, що відбулася прагматизація ціннісної свідомості молодого покоління та підвищення значення таких цінностей, як матеріальні блага, задоволення, квартира i дорогі речі, високооплачувана робота, престижний університет, кар'єра й успіх за будь-яку ціну $[5,7]$.

Сучасний дослідник націоналізму Д. Бройї стверджує, що «кристалізація національної ідеології» протікає за умов активної взаємодії трьох факторів: влада (політичні інститути) - суспільство (суспільні верстви та групи) - «групи» (носії нових ідей та прагнень). У контексті молодіжного виховання ми можемо говорити про цікавий факт: всі три складові цього процесу поповнюються, головним чином, 3 лав студентської молоді, яка стає національною інтелігенцією і національною елітою. Тож процес ціннісного виховання студентства потрапляє до стратегічних інтересів держави [6].

Метою дослідження було виявити ціннісні орієнтації і життєві пріоритети у слухачів першого курсу Української військовомедичної академії (УВМА) 3 метою стимулювання їх розвитку, проведення корекції впродовж освітнього процесу i визначити їх вплив на навчання та майбутню професійну діяльність слухачів.

Матеріали і методи дослідження. У дослідженні був використаний опитувальник 3 18-ти тверджень щодо особистісних ціннісних орієнтацій. Досліджувані визначали пріоритетність цих тверджень для себе, виставляючи кожному з них бал від першого (найважливішого для себе) до вісімнадцятого (найменш значимого). В опитуванні взяли участь 119 слухачів першого курсу УВМА.

Статистичний аналіз даних проведено 3 використанням методів варіаційної статистики, кореляційного (коефіцієнт кореляції Спірмена), кластерного та покрокового дискримінантного аналізу 3 допомогою пакету програм STATISTICA 13.3. Ліцензія AXA905I924220FAACD-N.

Результати дослідження та їх обговорення. Життєві цінності людини формуються внаслідок їі виховання в навчальних закладах, у сім'ї та найближчому оточенні. Певний відбиток на формування системи таких цінностей здійснюють засоби масової інформації та обрана професія. Ми виходили $з$ розуміння того, що слухачі, які приходять на навчання в УВМА або уже мають сформовані ціннісні орієнтири, або ці життєві орієнтації перебувають на стадії їх викристалізовування. Підрахунок середніх значень рівня досліджуваних цінностей $\mathrm{y}$ молодих військових лікарів дав змогу ранжувати їх та побудувати низку обраних пріоритетів (табл. 1). Виявлено, що трьома найважливішими цінностями у житті слухачів $€$ :

1. Здоров'я (фізичне і психічне) обрали 62 слухача $(52,1 \%)$ - середнє значення цього 
твердження у всій групі опитаних становить 3,32 балів.

2. Любов (духовна і фізична близькість) пріоритетне твердження для 26 слухачів (21,8\%) при середньому значенні важливості твердження для всієї групи - 5,14 балів.
3. Щасливе сімейне життя, як пріоритетне твердження, обрали 22 слухача (18,5\%)середнє значення 5,14 балів.

Результати дослідження ціннісних орієнтацій особистості по їх значимості, бали

\begin{tabular}{|c|c|c|c|c|c|}
\hline \multirow[b]{2}{*}{ Твердження } & \multicolumn{5}{|c|}{ Показники } \\
\hline & $\mathrm{M} \pm \mathrm{m}$ & Coef.Var. & Median & Mode & $\begin{array}{c}\text { Частота } \\
\text { (кількість } \\
\text { повторень } \\
\text { на рівні } \\
\text { моди) }\end{array}$ \\
\hline $\begin{array}{l}\text { 1.Активна життєва позиція } \\
\text { емоційне насичене життя) }\end{array}$ & $10,47 \pm 0,41$ & 42,49 & 11,0 & 12,0 & 12 \\
\hline $\begin{array}{l}\text { 2.Життєва мудрість (зрілість суджень і } \\
\text { здоровий глузд, що досягаються } \\
\text { життєвим досвідом }\end{array}$ & $9,39 \pm 0,42$ & 48,45 & 10,0 & 14,0 & 14 \\
\hline 3.Здоров'я (фізичне і психічне) & $3,33 \pm 0,35$ & 115,80 & 1,0 & 1,00 & 62 \\
\hline 4.Цікава робота & $9,45 \pm 0,32$ & 37,03 & 10,0 & 11,0 & 16 \\
\hline 5.Краса природи і мистецтво & $14,94 \pm 0,30$ & 21,75 & 16,0 & 17,0 & 26 \\
\hline 6.Любов (духовна і фізична близькість) & $5,14 \pm 0,33$ & 70,30 & 4,0 & 3,00 & 26 \\
\hline $\begin{array}{l}\text { 7.Матеріально забезпечене життя } \\
\text { (відсутність матеріальних проблем) }\end{array}$ & $7,90 \pm 0,40$ & 55,63 & 7,0 & 4,00 & 16 \\
\hline 8.Наявність хороших вірних друзів & $8,68 \pm 0,35$ & 44,41 & 8,0 & 5,00 & 14 \\
\hline $\begin{array}{l}\text { 9.Громадське визнання ( повага в } \\
\text { колективі, товаришів, суспільстві) }\end{array}$ & $11,69 \pm 0,41$ & 38,08 & 12,0 & 12,0 & 14 \\
\hline $\begin{array}{l}\text { 10.Пізнання (можливість поглиблення } \\
\text { своєї освіти, розширення кругозору, } \\
\text { загальної культури, інтелектуальний } \\
\text { розвиток) }\end{array}$ & $9,31 \pm 0,36$ & 42,20 & 9,0 & 9,00 & 17 \\
\hline $\begin{array}{l}\text { 11. Продуктивне життя (максимально } \\
\text { повне використання своїх можливостей, } \\
\text { сил, здібностей) }\end{array}$ & $8,31 \pm 0,36$ & 46,86 & 8,0 & 11,0 & 13 \\
\hline $\begin{array}{l}\text { 12. Розвиток (робота над собою, постійне } \\
\text { фізичне і духовне удосконалення) }\end{array}$ & $8,09 \pm 0,34$ & 46,07 & 8,0 & 7,00 & 13 \\
\hline $\begin{array}{l}\text { 13.Розваги (приємне проведення часу, } \\
\text { відсутність обов'язків) }\end{array}$ & $14,35 \pm 0,33$ & 24,75 & 15,0 & 18,0 & 20 \\
\hline $\begin{array}{l}\text { 14.Свобода (самостійність, незалежність } \\
\text { в судженнях і вчинках) }\end{array}$ & $8,41 \pm 0,42$ & 54,00 & 8,0 & 12,0 & 13 \\
\hline 15. Щасливе сімейне життя & $5,14 \pm 0,42$ & 88,65 & 3,0 & 2,00 & 22 \\
\hline $\begin{array}{l}\text { 16.Щастя інших, благополуччя, розвиток } \\
\text { i удосконалення інших людей, свого } \\
\text { народу) }\end{array}$ & $12,72 \pm 0,41$ & 35,30 & 14,0 & 17,0 & 19 \\
\hline $\begin{array}{lll}\begin{array}{l}\text { 17.Творчість } \\
\text { діяльності) }\end{array} & \text { (можливість } & \text { творчої } \\
\end{array}$ & $15,20 \pm 0,31$ & 22,21 & 16,0 & 18,0 & 33 \\
\hline $\begin{array}{l}\text { 18. Впевненість у собі ( } \begin{array}{c}\text { внутрішня } \\
\text { гармонія, свобода } \\
\text { протиріч і сумнівів) }\end{array} \\
\text { внутрішніх }\end{array}$ & $8,06 \pm 0,41$ & 54,86 & 8,0 & Multiple & 11 \\
\hline
\end{tabular}

Вибір саме таких тверджень, як ціннісних орієнтацій, свідчить, що досліджувана група - це молоді люди, які вступили в таку фазу 1. Творчість (можливість творчої свого життя, коли питання любові, сексуальних стосунків, пошук супутника життя i створення власної родини $\epsilon$ діяльності). Для 33 слухачів $(27,7 \%)$ це твердження $є$ цінністю найменшої особистої ваги (середнє значення - 15,2 балів).

найважливішими завданнями. Найменш важливими або незатребуваними виявилися такі цінності як: 
2. Краса природи i мистецтво найменш важливе для 26 слухачів $(21,8 \%)$ 3 середнім значенням 14,94 бали.

3. Розваги (приємне проведення часу, відсутність обов'язків) - не важливе для 20 слухачів $(16,8 \%)$ з середнім значенням ваги цінності 14,35 балів.

Попередній аналіз визначення ціннісних орієнтацій слухачів показує, що їм притаманні цілком природні особистісні цінності пересічної молодої людини. В той же час їх не цікавлять розваги, творчість, краса природи та мистецтво, що може свідчити про серйозність ставлення слухачів до свого професійного вибору.

Ретельний аналіз результатів дослідження ціннісних орієнтацій особистості за їх значимістю наведені в табл. 1. Тут доцільно підкреслити, що більшість досліджуваних показників хоча і мають моду (крім одного показника), але вона охоплює від 10,1\% до 16,8\% опитаних слухачів. Навіть в тому випадку, коли частота випадків на рівні моди досягає 52,1\% (62 слухача) інші слухачі мають дуже різноманітні думки щодо якості свого фізичного і психічного здоров'я, про що свідчить найбільший $\mathrm{y}$ цьому дослідженні коефіцієнт варіації оцінки цього параметру - 115,8\%. Переважна більшість слухачів мають одностайну думку тільки в 10,1\%-16,8\% випадків. Таких параметрів спостерігається $72,2 \%$, що свідчить про суттєву неоднорідність думок опитаних слухачів. Зважаючи на отримані результати, для проведення подальшого аналізу досліджувану групу доцільно розбити на дві підгрупи з більш однорідними відповідями слухачів.

Експериментально отримані результати рейтингу ціннісних орієнтацій 3 допомогою кластерного аналізу методом $k$-середніх дали змогу виділити дві підгрупи з різним профілем пріоритетів. Було отримано дві підгрупи 3 наближеним до 1:2 співвідношенням кількості осіб у першій та другій підгрупах (у 1-й підгрупі 44 слухача (37\%) та у 2-й підгрупі 75 слухачів - 63\%). Значення стандартизованих профілів ціннісних орієнтацій для цих підгруп наведені на графіку (рис. 1).

Можна зазначити, що отримані профілі ціннісних орієнтацій в обох виділених підгрупах певним чином тотожні. Коефіцієнт кореляції Спірмена для профілів цих підгруп становить 0,56 $(\mathrm{p}<0,05)$. 
уподобань. У представників 1-ї підгрупи найменшими коливаннями відзначається показник «розваги (приємне проведення часу, відсутність обов'язків)», що свідчить про їх цілеспрямованість і орієнтованість на подолання труднощів, які виникають при виконанні професійних обов'язків.

У табл. 2 наведені числові характеристики ціннісних орієнтацій слухачів обох підгруп 3 позначенням достовірності різниці їх середніх та дисперсій. Необхідно відзначити, що як середні, так i дисперсії аналізованих показників підгруп достовірно відрізняються. Виключенням $\epsilon$ показник 18 - впевненість у собі (внутрішня гармонія, свобода від внутрішніх протиріч i сумнівів), який має достатньо невисокий рівень в обох групах. Можна припустити, що молоді люди, які тільки починають навчатися в УВМА, почувають себе не надто впевненими в новому для них військовому середовищі.

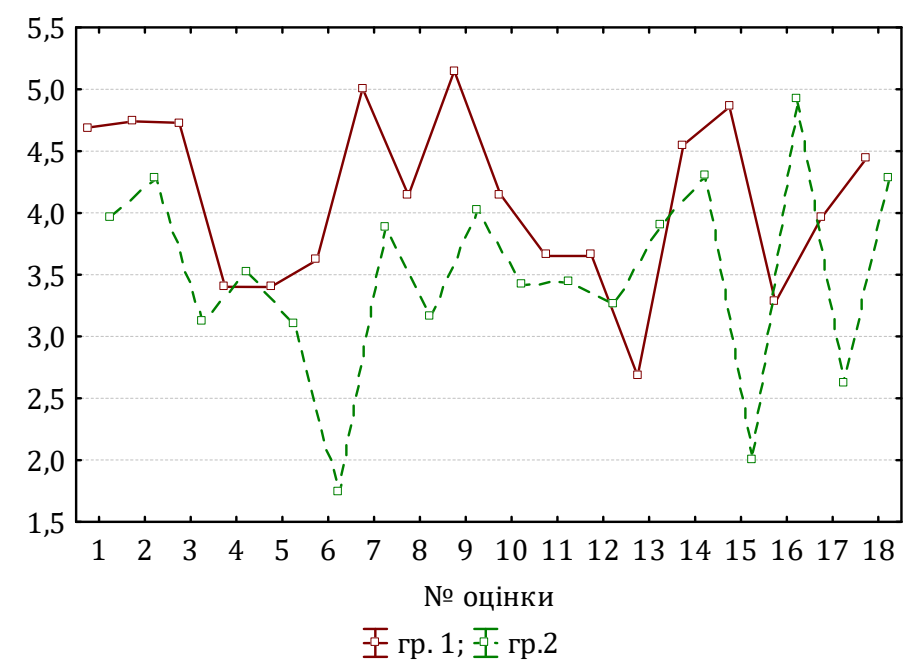

Рисунок 2. Профілі варіативності показників ціннісних орієнтацій представників 1-ї та 2-ї підгруп слухачів: 1, 2, ..., 18 - номер твердження для оцінки окремої ціннісної орієнтації (див. табл. 1).

Впевненість виробляється 3 набуттям професійного та життєвого досвіду.

Таблиця 2

Значення рейтингу ціннісних орієнтацій слухачів 1-ї та 2-ї підгруп, бали

\begin{tabular}{|c|c|c|c|c|c|}
\hline $\begin{array}{c}\text { № твердження на } \\
\text { рисунку }\end{array}$ & $\mathrm{M}_{1}$ & $\mathrm{M}_{2}$ & $\left(\mathrm{M}_{1}-\mathrm{M}_{2}\right) / \mathrm{M}_{1}, \%$ & $\sigma_{1}$ & $\sigma_{2}$ \\
\hline 1 & $8,68 \pm 0,71^{*}$ & $11,52 \pm 0,46$ & $-24,6$ & $4,69^{\wedge}$ & 3,97 \\
\hline 2 & $8,09 \pm 0,71^{*}$ & $10,16 \pm 0,49$ & $-20,6$ & $4,74^{\wedge}$ & 4,27 \\
\hline 3 & $4,32 \pm 0,71^{*}$ & $2,75 \pm 0,36$ & 57,2 & $4,73^{\wedge}$ & 3,12 \\
\hline 4 & $10,10 \pm 0,51^{*}$ & $9,07 \pm 0,41$ & 11,3 & $3,40^{\wedge}$ & 3,52 \\
\hline 5 & $14,20 \pm 0,51^{*}$ & $15,37 \pm 0,36$ & $-7,6$ & $3,40^{\wedge}$ & 3,10 \\
\hline 6 & $8,43 \pm 0,55^{*}$ & $3,21 \pm 0,20$ & 162,4 & $3,62^{\wedge}$ & 1,74 \\
\hline 7 & $9,04 \pm 0,75^{*}$ & $7,23 \pm 0,45$ & 25,2 & $5,01^{\wedge}$ & 3,87 \\
\hline 8 & $10,66 \pm 0,62^{*}$ & $7,52 \pm 0,37$ & 41,7 & $4,14^{\wedge}$ & 3,17 \\
\hline 9 & $11,84 \pm 0,78^{*}$ & $11,60 \pm 0,46$ & 2,1 & $5,15^{\wedge}$ & 4,02 \\
\hline 10 & $7,55 \pm 0,63^{*}$ & $10,35 \pm 0,39$ & $-27,1$ & $4,15^{\wedge}$ & 3,41 \\
\hline 11 & $6,09 \pm 0,55^{*}$ & $9,61 \pm 0,40$ & $-36,6$ & $3,65^{\wedge}$ & 3,43 \\
\hline 12 & $6,09 \pm 0,55^{*}$ & $9,27 \pm 0,38$ & $-34,3$ & $3,65^{\wedge}$ & 3,26 \\
\hline 13 & $15,27 \pm 0,40^{*}$ & $13,81 \pm 0,45$ & 10,6 & $2,70^{\wedge}$ & 3,89 \\
\hline 14 & $6,82 \pm 0,69^{*}$ & $9,35 \pm 0,50$ & $-27,1$ & $4,55^{\wedge}$ & 4,29 \\
\hline 15 & $9,18 \pm 0,73^{*}$ & $2,77 \pm 0,23$ & 231,1 & $4,86^{\wedge}$ & 2,01 \\
\hline 16 & $14,04 \pm 0,49^{*}$ & $11,95 \pm 0,57$ & 17,6 & $3,28^{\wedge}$ & 4,92 \\
\hline 17 & $13,66 \pm 0,60^{*}$ & $16,11 \pm 0,30$ & $-15,2$ & $3,96^{\wedge}$ & 2,61 \\
\hline 18 & $6,89 \pm 0,67$ & $8,75 \pm 0,50$ & 21,7 & 4,46 & 4,29 \\
\hline
\end{tabular}

Примітка: позначення як в таблиці $1 .{ }^{*}$ - наявність різниці середніх $\mathrm{M}_{1}$ та $\mathrm{M}_{2}$ за критерієм $\mathrm{t}$ Стьюдента на рівні $\mathrm{p} \leq 0,05$; $^{\wedge}$ - наявність різниці дисперсій $\left(\sigma_{1}{ }^{2}\right.$ та $\left.\sigma_{2}^{2}\right)$ за критерієм $\mathrm{F}$ Фішера на рівні $\mathrm{p} \leq 0,05$. $1,2, \ldots, 18$ - номер твердження для оцінки окремої ціннісної орієнтації (див. табл. 1).

Проаналізована таблиця дозволяє сформулювати ще декілька тверджень. Для представників 2-ї підгрупи більш значимими цінностями $є$ стан здоров'я та наявність вірних друзів, що свідчить про їх більшу комунікабельність, підкріплену значними функціональними резервами їх організму (стан здоров'я). Навпаки, для представників підгрупи 1 властивим є максимально повне використання своїх можливостей та постійне духовне та фізичне удосконалення, що свідчить про їх більшу індивідуалізованість та інтровертність. Вони більше схильні до творчості, а меншою цінністю для них $\epsilon$ розваги. Такі пріоритети, мабуть, дозволяють 
їм компенсувати певну хаотичність інших вподобань.

Узагальнюючи отримані дані слід констатувати, що за своїми ціннісними орієнтаціями виділені підгрупи є суттєво неоднаковими. Для них немає суттєвої різниці лише стосовно тверджень 4 (цікава робота) для обидвох підгруп це твердження має посереднє значення, 5 (краса природи i мистецтво) - для обидвох підгруп це твердження не $\epsilon$ високою цінністю, 9 (громадське визнання (повага в колективі, товаришів, суспільстві) - твердження середньої ваги.

Для підгрупи 1 пріоритетними цінностями на сучасному етапі життя $\epsilon$ здоров'я (фізичне і психічне), продуктивне життя (максимально повне використання своїх можливостей, сил, здібностей), розвиток (робота над собою, постійне фізичне і духовне удосконалення, свобода (самостійність, незалежність в судженнях і вчинках), впевненість у собі (внутрішня гармонія, свобода від внутрішніх протиріч і сумнівів).

Значимими для 1-ї підгрупи є такі ціннісні орієнтири як активна життєва позиція, що може проявлятися у повному, емоційно насиченому житті; можливість вдосконалення своєї освіти, розширення світогляду, загальної культури, інтелектуальний розвиток; життєва мудрість, що виявляється у зрілості суджень і здоровому глузді. Вагомими пріоритетами залишається любов в партнерських стосунках - духовна i фізична близькість, щасливе сімейне життя; матеріально забезпечене життя або, точніше, відсутність матеріальних проблем.

Найменш важливими цінностями для 1-ї підгрупи $є$ можливість творчої діяльності, краса природи i мистецтво. На даному життєвому етапі вони не переймаються щастям та благополуччям інших, розвитком та удосконаленням громадян своєї держави. Розваги, приємне проведення часу та безтурботне життя їх теж мало цікавить.

За своїми ціннісними орієнтирами представників першої підгрупи можна охарактеризувати як активних, самостійних, незалежних у діях і судженнях, орієнтованих на особисте удосконалення, професійне зростання, розширення власного світогляду 3 дещо егоїстичним проявом своїх пріоритетів.

Серед найважливіших цінностей представників 2-ї підгрупи є фізичне і психічне здоров'я, любов, що має прояв у духовній i фізичній близькості, щасливому сімейному житті. Досить важливими для них $\epsilon$ матеріально забезпечене життя та наявність вірних друзів.

Цінностями другого рівня $\epsilon$ цікава робота, впевненість у собі, що проявляється у внутрішній гармонії, свободі від внутрішніх протиріч i сумнівів, особистий розвиток, постійне фізичне і духовне удосконалення, продуктивне життя 3 максимально повним використанням своїх можливостей, сил, здібностей, особиста свобода, що проявляється в самостійності, незалежності в судженнях та вчинках, зрілість суджень i здоровий глузд, які досягаються життєвим досвідом.

Неважливими для 2-ї підгрупи є активна життєва позиція, розваги, краса природи i мистецтво, творчість та можливість творчої діяльності.

Вибрані представниками 2-ї підгрупи твердження дозволяють зробити висновки, що їх життєві цінності орієнтовані на здорове, сімейне, матеріально забезпечене, урівноважене життя. Військова служба може розглядатися як основа і необхідне джерело для забезпечення такого життя. Враховуючи, що активна життєва позиція, можливість творчої діяльності для них є неважливими, а цікава робота, можливість особистого розвитку, продуктивне життя 3 використанням свої здібностей і можливостей займають проміжне значення, можна припустити, що вони готові виконувати шаблонну роботу, підпорядковуватися наказам. Вибір твердження - наявність вірних друзів, може свідчити, що це люди «команди», для яких значимими $€$ колектив, його принципи, громадська думка.

Будь-яка ціннісна орієнтація людини не може бути ізольованою. Вона завжди специфічним чином пов'язана 3 іншими ціннісними орієнтаціями. Причому цей зв'язок може бути як позитивним, так і негативним. Наявність позитивного зв'язку свідчить про таку асоціацію між ціннісними характеристиками, коли посилення чи послаблення однієї ціннісної орієнтації веде до відповідного зрушення іншої. Роль позитивних зв'язків полягає в синхронному зміненні ціннісних функцій в одну сторону, що поглиблює їх асиметрію в порівнянні з іншими функціями. У випадку існування негативних кореляційних зв'язків між ціннісними характеристиками посилення однієї 3 них стимулює послаблення іншої. Роль таких зв'язків у цілісній системі ціннісної орієнтації 
людини пов'язана з ефектом врівноваження та стабілізації окремих ціннісних функцій. Тому, подальший аналіз механізмів формування ціннісної системи слухача доцільно проводити, розглядаючи окремо наявність достовірних $(\mathrm{p}<0,05)$ позитивних та негативних

кореляційних

зв'язків, проаналізованих ціннісних характеристик.

Структура позитивних та негативних кореляційних зв'язків ціннісних орієнтацій для всієї підгрупи обстежених представлена на рис. 3.

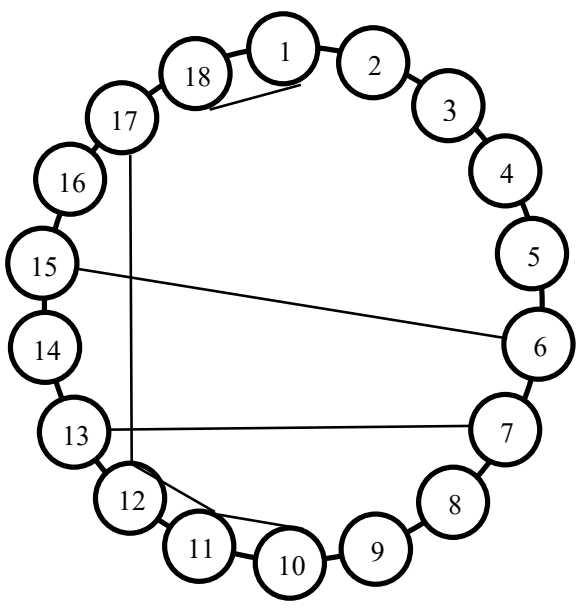

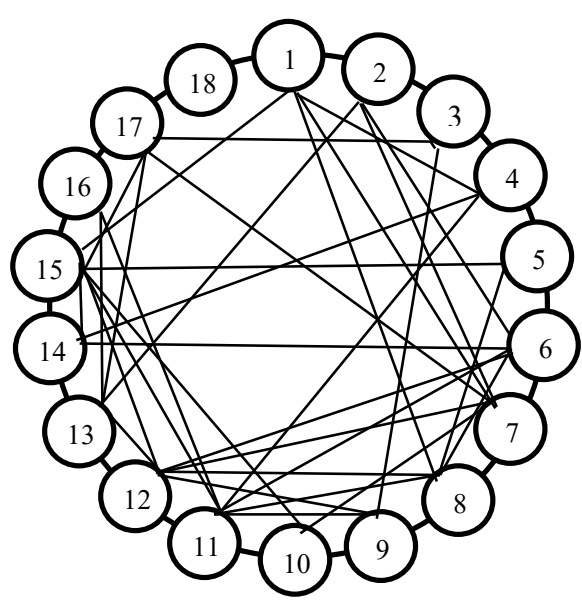

б

Рисунок 3. Структура позитивних та негативних кореляційних зв'язків ціннісних орієнтацій для всієї підгрупи обстежених: а - структура позитивних кореляційних зв'язків; б структура негативних кореляційних зв'язків; $1,2, \ldots, 18$ - номер твердження для оцінки окремої ціннісної орієнтації (див. табл. 1).

Аналіз складових (рис. 3) свідчить про те, що переважна більшість кореляційних зв'язків має негативний характер. Це доказує, що система цінностей слухачів у переважній більшості $є$ врівноваженою та стабільною із значною можливістю гармонізації своїх ціннісних функцій. Позитивні зв'язки тут відіграють роль підсилювача окремих ціннісних орієнтацій (рис.За). Зокрема, якщо особа вибирає твердження «активна життєва позиція», то для неї буде значимим твердження - впевненість у собі, свобода від внутрішніх протиріч і сумнівів (твердження 1та18). Якщо пріоритетним $\epsilon$ продуктивне життя 3 можливістю максимального використання своїх сил та здібностей, то значимими будуть розвиток особистості, постійне фізичне і духовне удосконалення, можливість удосконалення своєї освіти, розширення світогляду, інтелектуальний розвиток (твердження 11та10,11 та 12). Особи, для яких найважливішою цінністю $\epsilon$ матеріальне забезпечене життя, будуть віддавати перевагу розвагам, веселому проведенню часу, безтурботному життю (твердження 13 та 7). Зв'язок твердження 15 щасливе сімейне життя цілком зрозуміло грунтується на усвідомленому значенні духовної і фізичної близькості в подружній парі (6).

Обернено пропорційних залежностей у результатах дослідження виявлено набагато більше (рис. 3б). Аналіз деяких з них показав, що чим важливішим для досліджуваних $\epsilon$ твердження щодо їх повного, емоційно насиченого життя, тим менш важливими $\epsilon$ цікава робота, матеріальне забезпечення (хоча не зрозуміло як можна жити повним життям без належного його забезпечення), наявність вірних друзів, сімейне життя (твердження 13 показниками $4,7,8,15)$. Тут можна зробити висновок про деяку інфантильність або недосформованість життєвих орієнтирів.

Якщо для слухачів пріоритетом $\epsilon$ максимальне використання своїх сил i здібностей, то воно заперечує щастя інших людей (11 та 16). Особливо насторожує той факт, що для слухачів взагалі не є життєвою цінністю щастя інших людей, благополуччя, розвиток і удосконалення свого народу. Це може свідчити про їх громадянську пасивність, визнання своєї неспроможності впливати на процеси, що відбуваються у соціумі або недосформованість національних патріотичних почуттів.

Виявлені протиріччя в ціннісних орієнтаціях загальної групи слухачів свідчить 
про певну неоднорідність аналізованої групи, окремі члени якої мають протилежні ціннісні орієнтації. Тому, для виявлення механізмів формування системи ціннісних орієнтацій доцільно розглянути сукупність кореляційних зв'язків у підгрупі 1 та підгрупі 2 окремо. Структура позитивних та негативних кореляційних зв'язків ціннісних орієнтацій для підгрупи 1 обстежених слухачів представлена на рис. 4. Аналіз структури кореляційних зв'язків цієї підгрупи показує, що, по-перше, кількість позитивних та негативних зв'язків, характерних для цієї підгрупи $\epsilon$ невеликою. Це свідчить про

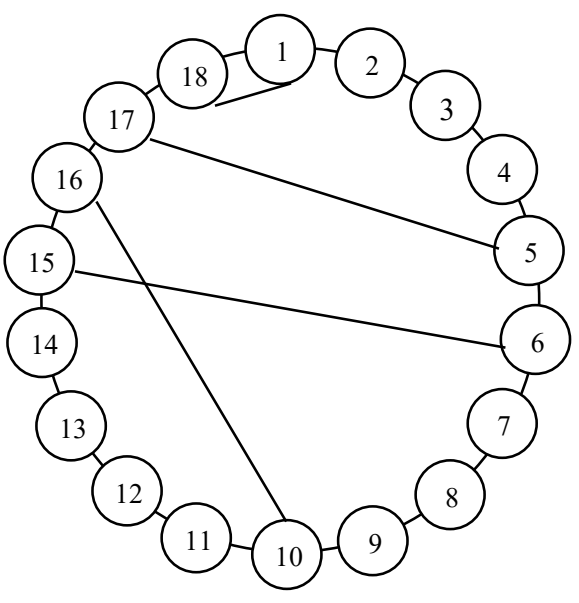

a автономність більшості ціннісних функцій. Подруге, така автономність $є$ своєрідним механізмом пришвидшення пристосування до умов праці та життєдіяльності. Адже, автономній функції немає необхідності в узгодженні своєї спрямованості 3 іншими функціями. Тому, адаптація до зовнішнього середовища відбувається швидше та легше. 3 іншого боку, такий механізм пристосування має окремі вади, оскільки автономна функція не завжди адекватно може реагувати на зміни зовнішнього середовища, а коректуючих механізмів у цьому випадку немає.

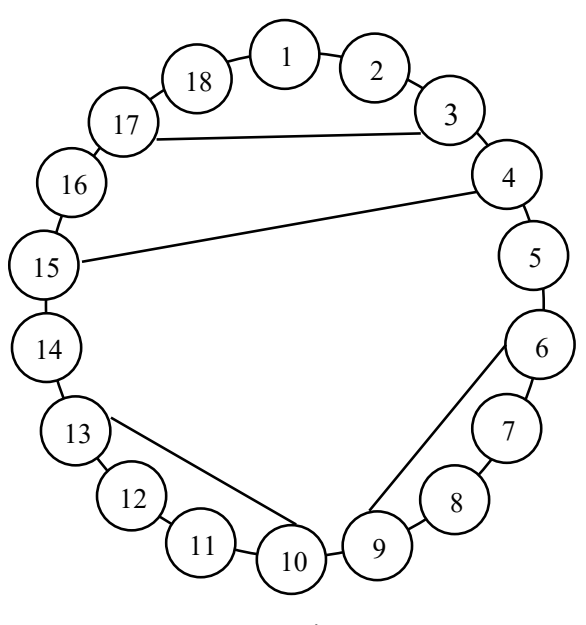

б

Рисунок 4. Структура позитивних та негативних кореляційних зв'язків ціннісних орієнтацій для підгрупи 1 обстежених слухачів: а - структура позитивних кореляційних зв'язків; б - структура негативних кореляційних зв'язків; $1,2, \ldots, 18$ - номер твердження для оцінки окремої ціннісної орієнтації (див. табл. 1).

Зокрема, для представників цієї підгрупи спостерігається пряма залежність, візуалізована на рис. 4а, активної життєвої позиції з впевненістю у собі, свободі від внутрішніх сумнівів і протиріч (твердження 1 та 18). Для них існує пряма залежність між творчістю або можливістю творчої діяльності 3 мистецтвом і красою природи (твердження 5 та 17). Якщо для особи значимими $€$ можливість поглиблення своєї освіти, розширення світогляду, загальної культури та інтелектуальний розвиток, то для неї буде важливими щастя інших людей (твердження 10 та 16). Відповідно, у прямій залежності перебувають цінності сімейного життя і любов до супутника життя (твердження 6 та 15).

Обернені залежності тверджень для 1-ї підгрупи представлені на рис. 4б. Вибір твердження 3 - фізичне і психічне здоров'я заперечує можливість творчої діяльності (твердження 17). Якщо надається перевага цікавій роботі, то вона нівелює цінність

щасливого сімейного життя (твердження 4 та 15); якщо вибирають громадське визнання, повагу в колективі, в суспільстві, то любов перестає бути життєвим пріоритетом (твердження 6 та 9). Вибір можливості вдосконалення своєї освіти, інтелектуального розвитку певним чином заперечує розваги та проведення часу без користі (твердження 10 та 13).

Структура позитивних та негативних кореляційних зв'язків ціннісних орієнтацій для підгрупи 2 обстежених слухачів представлена на рис. 5. Аналіз цих зв'язків дає можливість констатувати, що, по-перше, їх структура корінним чином відрізняється від структури зв'язків у підгрупі 1. По-друге, спираючись на той факт, що кількість негативних зв'язків ціннісних орієнтацій у цій підгрупі набагато перевищує кількість позитивних, можна стверджувати, що система ціннісних орієнтацій в цій підгрупі $\epsilon$ стабільнішою, ніж в підгрупі 1. По-третє, 
досить велика зв'язність між ціннісними орієнтаціями в цій підгрупі свідчить про потенційно кращу спроможність адаптації до

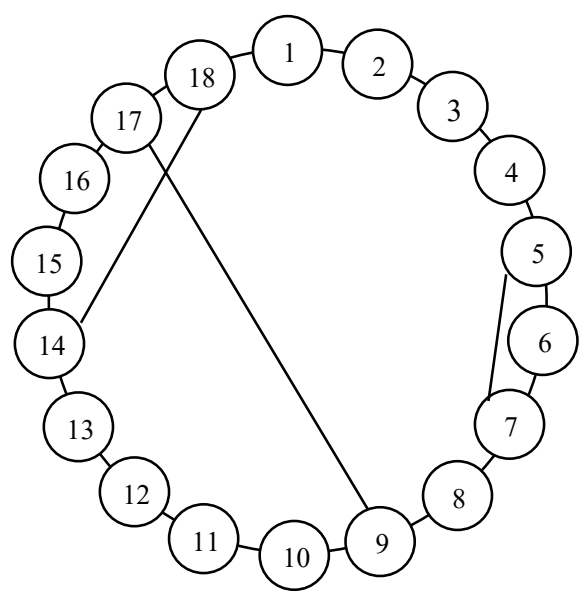

a змін зовнішнього середовища представників підгрупи 2, хоча термін цієї адаптації може бути тривалішим ніж в групі 1.

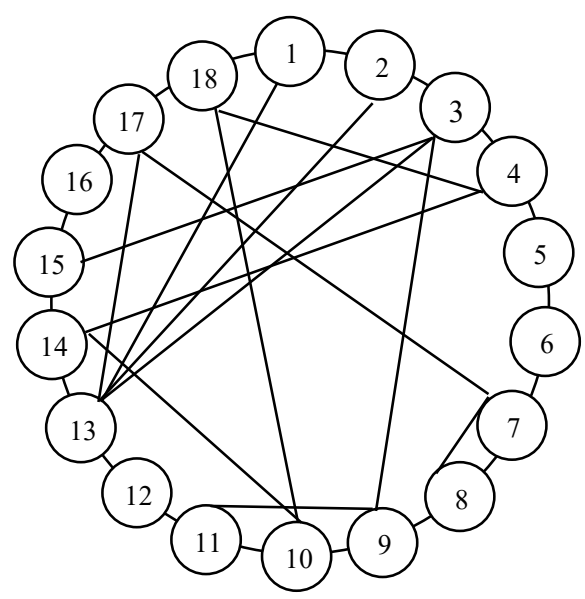

б

Рисунок 5. Структура позитивних та негативних кореляційних зв'язків ціннісних орієнтацій для підгрупи 2 обстежених слухачів: а - структура позитивних кореляційних зв'язків; б - структура негативних кореляційних зв'язків; $1,2, \ldots, 18$ - номер твердження для оцінки окремої ціннісної орієнтації (див. табл. 1).

Зокрема, для цієї підгрупи (рис.5а) спостерігається пряма залежність особистої свободи, що виражається у самостійності і незалежності суджень та вчинків 3 впевненістю у собі (твердження 14 та 18), матеріально забезпечене життя з мистецтвом та красою природи (твердження 7 та 5), можливість займатися творчою діяльністю 3 громадським визнанням та повагою у колективі (твердження 9 та 17).

Обернені залежності для 2-ї підгрупи проявляються таким чином (рис. 5б). Чим важливішим $\epsilon$ фізичне і психічне здоров'я, тим менш значимими суспільне визнання, розваги, щасливе сімейне життя (3 з показниками $9,13,15)$. Чим пріоритетнішим $\epsilon$ вибір цікавої роботи, тим менш важливою $є$ особистісна свобода (4 та 14). Вибір матеріально забезпеченого життя не передбачає наявність хороших вірних друзів і можливість творчої діяльності (7 3 показниками 8,17), 3 чого можна зробити висновок про наявність матеріальних проблем i значимість їх подолання для слухачів.

Можна констатувати, що кожна 3 виділених підгруп слухачів має свої

\section{Висновки}

1. Випускник вищої школи - слухач УВМА має в цілому сформовану систему цінностей і життєву позицію, що визначатиме його подальший шлях самореалізації, особливості в формуванні системи ціннісних орієнтацій. Ці особливості мають позитивні та негативні сторони, які підкреслюють специфічність та багатоманітність механізмів пристосування до умов професійної діяльності та життя в цілому. Але їх багатоманіття $\epsilon$ позитивним 3 точки зору можливостей швидкого чи більш повільного пристосування як у військовому так i y цивільному середовищі. Період навчання в УВМА має створити умови для повного завершення системи ціннісних орієнтирів слухачів, щоб кожна особа в залежності від своїх вподобань змогла зайняти таку суспільну нішу, яка буде влаштовувати і суспільство і конкретного його члена. Ціннісний рівень свідомості слухачів визначається їх рівнем історичної і культурної компетенції. Отримати такі знання слухачі УВМА зможуть не лише під час вивчення предметів гуманітарного циклу, а й на інших військових та профільних дисциплінах. Використання у освітньому процесі УВМА знань історико-культурної спадщини українського народу збагачуватиме духовність, культуру, моральність молодої людини.

самовдосконалення, професійного становлення та досягнення успіху у житті.

2. В результаті дослідження було виділено дві підгрупи, які мають різні ціннісні орієнтації, які представляють окремі 
механізми пристосування до професійної діяльності та життєзабезпечення.

3. Головною метою виховання слухачів в Українській військово-медичній академії має стати громадянське і національнопатріотичне виховання, спрямоване на адекватний розвиток особистості молодого фахівця - військового медика, готового до захисту Вітчизни, її територіальної цілісності, демократичних i гуманістичних цінностей нашого суспільства.

4. В дослідженні було виявлено, що для слухачів першого курсу УВМА щастя інших людей, благополуччя, розвиток i удосконалення свого народу не $\epsilon$ пріоритетною цінністю. Це може свідчити про їх громадянську пасивність, визнання своєї неспроможності впливати на процеси, що відбуваються у соціумі або недосформованість національних патріотичних почуттів.

\section{Література}

\section{References}

1. Law of Ukraine "On Education ( 2017). Bulletin of the Verkhovna Rada (VVR), № 38-39, p.380 https://zakon.rada.gov.ua/laws/show/2145-19\#Text

2. Lappo, V. (2014). Education of spiritual values of student youth by means of national culture. Scientific Bulletin of Melitopol State Pedagogical University. Ser: Pedagogy. 2. 142-146.

3. Bekh, I.D. (2008). Education of personality: Textbook. K. Lybid, 848.

4. Goncharenko, S.V. (1997). Ukrainian pedagogical dictionary. K., 376.

5. Rashidov, S.F. (2014). Education in student youth of values of civil society: experience of theoretical
5. Формування ціннісних орієнтацій слухачів має відбуватися при створенні сприятливого психолого-емоційного клімату в академічному середовищі. Особливу роль у формуванні цінностей відіграє викладач. Саме його ставлення до роботи, до подій, що відбуваються в суспільстві, високий професіоналізм, культурний i мовленнєвий рівень, державницька позиція, ерудиція, самодисципліна, власний приклад сприяють формуванню відповідних цінностей у слухачів. Іноді приклад власної моральної поведінки викладача-офіцера $€$ найкращим виховним чинником для слухачів.

6. Впродовж навчання слухачів в УВМА група морально-психологічного забезпечення має здійснювати коригування ціннісних орієнтирів слухачів. 3 цією метою мають бути розроблені заходи додаткових виховних впливів.

conceptualization. Spirituality of personality: methodology, theory and practice. V2. 165-176.

6. Klyuy, A.I. (2013). Political values in the process of educating student youth. Visnyk of Dnipropetrovsk University. Series: Philosophy. Sociology. Politology. Vol. 21, issue 23 (1). 98-102.

7. Mudryk, N.I., Goncharenko, I.F. (2018). The system of values of modern youth: a literary analysis and a statement on the example of the valuesof UMMA students. Military Medicine of Ukraine. Vol.18. Special edition. 173-176.

\title{
ЦЕННОСТНЫЕ ОРИЕНТАЦИИ СЛУШАТЕЛЕЙ КАК НЕОБХОДИМАЯ ПРЕДПОСЫЛКА ФОРМИРОВАНИЯ КОМПЕТЕНТНОГО ВОЕННО-МЕДИЦИНСКОГО СПЕЦИАЛИСТА
}

\author{
И.С. Тринька, В.В. Кальниш, Н.И. Мудрик, О.В. Числицкая
}

Украинская военно-медицинская академия, г. Киев, Украина

Введение. Формирование компетентного военно-медицинского специалиста является процессом сложным, который определяется не только суммой полученных профессиональных знаний, умений и навыков, сформированных компетенций, но и системой ценностных ориентаций, ценностного самосознания молодого специалиста. Процесс ценностного воспитания военного, военного медика в частности, входит в стратегические интересы нашего государства.

Целью исследования было определение ценностных ориентаций и жизненных приоритетов у слушателей первого курса УВМА для дальнейшего стимулирования их развития или проведения коррекции в течение обучения в УВМА.

Материалы и методы. В проведении исследования был использован опросник из 18 утверждений относительно личностных ценностных ориентаций. В опросе приняли участие 119 слушателей первого курса УВМА. Статистический анализ данных был проведен с использованием методов вариационной статистики, корреляционного (коэффициент корреляции Спирмена), кластерного и пошагового дискриминантного анализа с помощью пакета программ STATISTICA 13.3. (AXA905I924220FAACD-N).

Результаты. Анализ определения ценностных ориентаций слушателей показывает, что им присущи естественные личностные ценности обычного молодого человека (важнейшими ценностями в жизни 
слушателей является физическое и психическое здоровье, счастливая семейная жизнь, любовь) с отсутствием заинтересованности в развлечениях, творчества, красоте природы и искусства. Результаты исследования позволяют сделать вывод, что молодые люди, которые только начинают учиться в УВМА, чувствуют себя не слишком уверенными в новой для них военной среде. Экспериментально полученные результаты рейтинга ценностных ориентаций с помощью кластерного анализа методом $k$ средних позволили выделить две подгруппы с различным профилем приоритетов с приближенным соотношением количества лиц в первой и второй подгруппах как 1: 2.По своим ценностным ориентирам представителей первой подгруппы можно охарактеризовать как активных, самостоятельных, независимых в действиях и суждениях, ориентированных на личное совершенствование, профессиональный рост, расширение собственного мировоззрения несколько эгоистичным проявлением своих приоритетов. Для подгруппы 1 приоритетными ценностями на современном этапе жизни является здоровье (физическое и психическое), продуктивную жизнь (максимально полное использование своих возможностей, сил, способностей), развитие (работа над собой, постоянное физическое и духовное совершенствование, свобода (самостоятельность, независимость в суждениях и поступках), уверенность в себе (внутренняя гармония, свобода от внутренних противоречий и сомнений). Обучение в академии они рассматривают как площадку для реализации своих жизненных планов. Избранные представителями 2-й подгруппы утверждение позволяют сделать выводы, которые жизненные ценности ориентированы на здоровое, семейное, материально обеспеченная, уравновешенное жизни. Военная служба может рассматриваться как основа и необходимое источник для обеспечения такой жизни. Учитывая, что активная жизненная позиция, возможность творческой деятельности для них является неважными, а интересная работа, возможность личного развития, продуктивную жизнь с использованием свои способностей и возможностей занимают промежуточное значение, можно предположить, что они готовы выполнять шаблонную работу, подчиняться приказам. Это люди «команды», для которых значимыми являются коллектив, его принципы, общественное мнение. Система ценностных ориентаций в этой подгруппе является стабильной, чем в подгруппе 1, свидетельствует о потенциально лучшую способность адаптации к изменениям внешней среды.

Выводы. Система ценностных ориентаций слушателей находится на стадии ее завершения. Особое внимание при организации образовательного процесса следует уделять формированию у слушателей активной жизненной позиции, ориентированной на ответственное отношение к собственному профессиональному росту и общественной жизни, формированию национально-патриотических чувств.

Ключевые слова: жизненные ценности, ценностные ориентации, внутренняя гармония, личное совершенствование, профессиональный рост, активная жизненная позиция.

\title{
VALUE ORIENTATIONS OF STUDENTS AS A NECESSARY BACKGROUND FOR THE FORMATION OF A COMPETENT MILITARY MEDICAL SPECIALIST
}

\author{
I. Trinka, V. Kalnysh, N. Mudryk, 0. Chyslitska
}

\author{
Ukrainian Military Medical Academy
}

Introduction. The formation of a competent military medical specialist is a complex process, which is determined not only by the sum of the acquired professional knowledge, skills and abilities, formed competencies, but also by the system of value orientations, value consciousness of a young specialist. The process of value education of the military, military physician in particular, is included in the strategic interests of our state.

The purpose of the study was to determine the value orientations and life priorities of the first-year students of the UVMA to further stimulate their development or carry out correction during their studies at the UMMA.

Materials and methods. In the study, a questionnaire of 18 statements about personal value orientations was used. 119 students of the first course of UMMA took part in the survey. Statistical analysis of the data was carried out using the methods of variation statistics, correlation (Spearman's correlation coefficient), cluster and stepwise discriminant analysis using the STATISTICA 13.3 software package. License AXA9051924220FAACD-N.

Results. Analysis of the established values of the students displays that the students possess natural values of an average young person (the primary values of the students are physical and mental health, happy family life, love) with no interest in entertainment, creative activities, beauty of nature and art. The research results allow to conclude that young people at the beginning of their studies at the UMMA are still awkward in the military surrounding that is new to them. The students in accordance with their values established through $k$-means clustering rating were divided into two groups under the key priorities; ratio between the number of students in the first and second group is 1:2. Representatives of the first group are seen as active, independent in their actions and opinions, oriented at selfdevelopment, professional growth, broadening of their horizons with rather egoistic display of the priorities. The first group currently prioritises health (physical and mental), productive life (maximum exploiting of opportunities, powers, abilities), development (self-development, constant physical and mental development), freedom (independence in opinions and actions), self-confidence (inner harmony, freedom from internal contradictions and doubts). Studies at the Academy are viewed as a basis for realisation of their life plans. The choices made by the second 
group witness that their values are concentrated at healthy, family-like, wealthy, moderate life. Military service may be considered as a basis and necessary source of such way of living. Given that active life, creative activities are not important for them; and interesting job, self-development, productive life with exploiting of abilities and opportunities are of non-significant value, one may presume that they are prepared to do repetition work, follow the orders. These are the people of "a team", they value the collective, its principles and public opinion. The values system in this group is more stable as compared to that of first group and is potentially more adaptable to the external changes.

Conclusions. The system of value orientations of listeners is at the stage of its completion. When organizing the educational process, special attention should be paid to the formation of an active life position in students, focused on a responsible attitude to their own professional growth and social life, the formation of national-patriotic feelings.

Key words: life values, value orientations, inner harmony, personal improvement, professional growth, active life position.

Конфлікт інтересів: відсутній.

Conflicts of interest: authors have no conflict of interest to declare.

\section{Відомості про авторів:}

Tрінька I.C. C,E,F - полковник медичної служби, кандидат медичних наук, доцент, начальник кафедри авіаційної, морської медицини та психофізіології Української військово-медичної академії, м. Київ.

Кальниш В.B. A,C,D - доктор біологічних наук, професор, професор кафедри авіаційної, морської медицини та психофізіології Української військово-медичної академії, м. Київ.

Мудрик H.I. A,B,C,D - кандидат педагогічних наук, доцент, доцент кафедри авіаційної, морської медицини та психофізіології Української військово-медичної академії, м. Київ.

Числіцька O.B. B,C,D - кандидат психологічних наук, старший науковий співробітник науковоорганізаційного відділення Української військово-медичної академії, м. Київ.

$A$ - концепція та дизайн дослідження; $B$ - збір даних; $C$ - аналіз та інтерпретація даних;

$D$ - написання статmi; $E$ - редагування статmi; F- остаточне затвердження статті.

Сведения об авторах:

Тринька И.С. - полковник медицинской службы, кандидат медицинских наук, доцент, начальник кафедры авиационной морской медицины и психофизиологии Украинской военно-медицинской академии., г. Киев.

Кальниш В.В. - доктор биологических наук, профессор, профессор кафедры авиационной морской медицины и психофизиологии Украинской военно-медицинской академии., г. Киев.

Мудрик Н.И. - кандидат педагогических наук, доцент, доцент кафедры авиационной морской медицины Украинской военно-медицинской академии., г. Киев.

Числицкая О.В.- кандидат психологических наук, старший научный сотрудник научноорганизационного отделения Украинской военно-медицинской академии., г. Киев.

Information about the authors:

Trinka I. S. C,E,F - Colonel of Medical Service, Candidate of Medical Sciences, Associate Professor, head of the department of Aviation, Maritime Medicine and Psychophysiology of the Ukrainian Military Medical Academy, Kyiv, ORCID ID: 0000-0002-9095-8321.

Kalnysh V. V. A,C,D - Doctor of Biological Sciences, Professor, Professor of the Department of Aviation, Maritime Medicine and Psychophysiology of the Ukrainian Military Medical Academy, Kyiv, https://orcid.org/0000-0002-5033-6659

Mudryk N.I. A,B,C,D - Candidate of Pedagogical Sciences, Associate Professor, Associate Professor of Aviation, Maritime Medicine and Psychophysiology of the Ukrainian Military Medical Academy, Kyiv, https://orcid.org/0000-0003-4909-8850

Chyslitska O.V. B,C,D - Candidate of Psychological Sciences, Senior Researcher of the Scientific and Organizational Department of the Ukrainian Military Medical Academy, Kyiv. https://orcid.org/0000-0003-04164961. Email: olgachisel@gmail.com

$A$ - research concept and design; $B$ - collection and/or assembly of data; $C$ - data analysis and interpretation; $D$ - writing the article; $E$ - critical revision of the article; $F$ - final approval of the article.

Адреса для листування: вул. Московська, 45/1, буд. 33, м. Київ 01015 